\title{
Female effect in sheep. I. The effects of sexual receptivity of females and the sexual experience of rams
}

\author{
R Gonzalez *, P Orgeur, P Poindron, JP Signoret * *
}

Laboratoire de Comportement Animal, INRANCNRS, URA 1291, Nouzilly 37380 Monnaie, France

(Received 20 July, 1990; accepted 10 December, 1990)

\begin{abstract}
Summary - When in contact with receptive or non-receptive ewes, the presence of females increased LH peak frequency both in experienced and inexperienced rams $(P<0.05)$. The highest response was found in experienced rams stimulated by sexually receptive ewes. In this group only, the mean testosterone levels increased during stimulation $(P<0.05)$. Sexual behavior did not differ between experienced and inexperienced males. The sexual receptivity of the females and the sexual experience of rams appear to interact and thus facilitate the rams' $\mathrm{LH}$ and testosterone responses to the presence of ewes.
\end{abstract}

\section{LH / testosterone / female effect / ram / female receptivity / sexual experience}

Résumé - Effet femelle chez les ovins. I. Rôle de l'état de réceptivité sexuelle des femelles et de l'expérience sexuelle des mâles. Soixante-huit béliers lle-de-France (36 sexuellement expérimentés, 32 inexpérimentés), ont été répartis en 3 groupes et mis en présence de femelles ovariectomisées, traitées ou non pour induire le comportement d'oestrus, ou maintenus isolés. Les taux plasmatiques de $\mathrm{LH}$ et de testostérone ont été mesurés à intervalle de 20 min pendant $6 \mathrm{~h}$. L'introduction de femelles, réalisée $3 h$ après le début des prélèvements sanguins, induit chez tous les mâles un accroissement significatif de la fréquence des épisodes de sécrétion de LH. Toutefois, la réponse est plus forte chez les sujets ayant une expérience sexuelle $(\mathrm{P}<0,05)$. Chez les mâles inexpérimentés, la réponse est indépendante de l'état physiologique des femelles. Au contraire, les béliers expérimentés réagissent plus fortement à la présence d'une femelle réceptive $(P<0,05)$. Ce n'est que dans ce dernier cas que le taux de testostérone circulant est significativement accru. Enfin, la réponse comportementale à la présence des femelles n'a pas été influencée par l'expérience des mâles.

LH / testostérone / effet femelle / ovin / réceptivité sexuelle / expérience sexuelle

\footnotetext{
* Present address: INTA, Sheep Reproduction Research Group, CC 277, 8400 Bariloche, Argentina.

** Correspondence and reprints.
} 


\section{INTRODUCTION}

In several mammalian species, sexual interactions have been reported to increase plasma LH and testosterone levels in males (mice: Macrides et al, 1975; Coquelin and Bronson, 1980; hamsters: Macrides et al, 1974; rats: Kamel et al, 1975; rabbit: Haltmeyer and Eik-Nes, 1969; boar: Ellendorff et al, 1975; bull: Katongole et al, 1971; ram: Sanford et al, 1974; Schanbacher et al, 1987; Gonzalez et al, 1988a, 1989; monkey: Herndon et al, 1981). The experiments have generally been carried out with sexually receptive females. However, the LH and testosterone responses to the presence of an estrous female can be observed in males displaying no sexual activity (Gonzalez et al, 1988a). This raises the question of the importance of the sexual receptivity of the stimulus females. The male's sexual experience may be another factor which could affect the quality of the endocrine response. This has been reported to be the case in rodents (rat: Kamel et al, 1975; mice: Maruniak and Bronson, 1976). In sheep, one report suggests that the stimulation by estrous ewes leads to a significant increase in $\mathrm{LH}$ and testosterone parameters in the sexually inexperienced ram (Yarney and Sanford, 1983). In this case, however, the males had experienced some contact with receptive females before the experiment began.

The aim of the present study was to determine the influence of female receptivity and the sexual experience of the male on the $\mathrm{LH}$ and testosterone responses in rams.

\section{MATERIALS AND METHODS}

\section{Animals}

Sixty-eight adult lle-de-France rams were used ( 36 sexually experienced and 32 inexperienced animals). The sexually inexperienced rams had been reared without any contact with females since weaning, and the others had been isolated from females for at least 2 months before the experiment began. Estrous behavior was induced in ovariectomized Ile-de-France ewes treated with progesterone $(100 \mathrm{mg}$ im) for $5 \mathrm{~d}$, and injected with estradiol benzoate $(50 \mu \mathrm{g}$ im) on the 7 th $d$. They were used as a stimulus after being verified as receptive on the 8 th $\mathrm{d}$. The nonreceptive ewes were ovariectomized, nontreated females of the same breed. All animals were kept indoors under natural day-length conditions, and provided with water and a diet of dehydrated lucerne and maize, plus straw and mineral supplement ad libitum.

\section{Experimental groups and schedule}

The rams were distributed into 3 groups of inexperienced $(11,11$ and 10 animals respectively) and 3 groups of experienced animals (12 animals in each). The experiment was conducted as a $2 \times 3$ factorial design with 2 degrees of male sexual experience (experienced or inexperienced) and 2 stimulation conditions (sexually receptive or non-receptive ewes) and with nonstimulated controls. The experiment was carried out over 2 consecutive days during the nonbreeding season, as it has been shown to be the period when the response to female stimulation is obvious (Schanbacher et al, 1987; Gonzales et al, 1989). Half of the rams from each group were tested on each of the 2 days. The rams were placed in $10-\mathrm{m}^{2}$ visually isolated pens, and at $3 \mathrm{~m}$ from other treatment groups. Blood samples were obtained by jugular venipuncture with vacutainers every $20 \mathrm{~min}$ for $6 \mathrm{~h}$ starting from $09.00 \mathrm{am}$. Two females were introduced in the treated groups after $3 \mathrm{~h}$ blood sampling (period 1: pretreatment) and remained with the males for the following $3 \mathrm{~h}$ (period 2: treatment).

\section{Behavioral observations}

During the treatment period, the sexual behavior of rams was recorded in the stimulated groups by an observer placed $2 \mathrm{~m}$ above the ground. Anogenital sniffing, nudging, flehmen, mounting and ejaculation were recorded between each blood sampling. 


\section{Hormone assays}

Blood samples were centrifuged and plasma stored at $-15^{\circ} \mathrm{C}$. LH and testosterone concentrations were each measured in a single assay by direct RIA methods in duplicate (Pelletier et al, 1982 and Garnier et al, 1978, respectively). The intra-assay coefficients of variation were $8.3 \%$ for $0.4 \mathrm{ng} / \mathrm{ml} \mathrm{LH}$ and $6.6 \%$ for $1 \mathrm{ng} / \mathrm{ml}$ testosterone respectively, and the detection levels were $100 \mathrm{pg} \mathrm{LH} / \mathrm{ml}$ and $200 \mathrm{pg}$ testosterone $/ \mathrm{ml}$. Purified OLH CY 1051 (= $2.1 \times \mathrm{NIH}$ - LU S1) was used as standard. LH peaks were identified using the Pulsar algorithm program involving a "smoothing window" used to compute the theoretical baseline (Merriam and Wachter, 1982). The smoothing window was chosen from 10 samples $(200 \mathrm{~min})$. Other hormonal parameters calculated were mean and basal LH concentrations (computed by Pulsar), and mean testosterone concentration.

\section{Statistical analysis}

LH peak frequency was analyzed by the MannWhitney U-test when considering the "treatment" and "experience" effects for each period separately. The same test was used for behavioral data. Intragroup comparisons between pretreatment and treatment periods were performed with the Wilcoxon matched-pairs signed-ranks test (Siegel, 1956). A response to the introduction of females was considered to have occurred when a significant increase in $\mathrm{LH}$ peak frequency was observed. All the reported significant differences from the nonparametric tests are 1-tailed. MANOVA test (Stevens, 1986) using a SYSTAT computer program was performed on the logarithmically transformed values of mean testosterone concentration across the different groups. The beginning of the treatment period was delayed $40 \mathrm{~min}$ relative to the introduction of females to take into account the lag in gonadal response following an LH peak (Terqui et al, 1980). ANOVAS (Sokal and Rohlf, 1981) were used to test the different contrasts for each variable. Intragroup comparisons were carried out between pretreatment and treatment periods by repeated measures analysis (Rich, 1983). The significance level accepted was $P<0.05$.

\section{RESULTS}

The introduction of receptive females increased the $\mathrm{LH}$ pulse frequencies both in sexually experienced and inexperienced rams. The 2 groups did not differ during the pre-experimental period, but after stimulation the LH pulse frequency was higher in the sexually experienced males (table I).

Table I. Mean LH pulse frequency (pulse/ram/3 h) and testosterone ( $\mathrm{ng} / \mathrm{ml}$ plasma) from sexually experienced (Exp) and inexperienced rams.

\begin{tabular}{|c|c|c|c|c|c|c|c|c|}
\hline & \multirow[t]{2}{*}{ Group } & \multicolumn{2}{|c|}{$\begin{array}{l}\text { Receptive } \\
\text { ewes }\end{array}$} & \multicolumn{2}{|c|}{$\begin{array}{c}\text { Non-receptive } \\
\text { ewes }\end{array}$} & \multicolumn{2}{|c|}{$\begin{array}{c}\text { Controls } \\
\text { (unstimulated) }\end{array}$} & \multirow[t]{2}{*}{$\begin{array}{l}\text { Pooled } \\
\text { SD }\end{array}$} \\
\hline & & Per 1 & Per 2 & Per 1 & Per 2 & Per 1 & Per 2 & \\
\hline \multirow[t]{2}{*}{ LH } & Exp & $0.25^{a}$ & $1.25^{b}$ & $0.08^{a}$ & $0.50^{c}$ & $0.16^{\text {ad }}$ & $0.08^{d}$ & \\
\hline & Inexp & $0.18^{a}$ & $0.63^{c}$ & $0.18^{a}$ & $0.72^{\mathrm{c}}$ & $0.50^{\mathrm{a}}$ & $0.70^{\mathrm{ac}}$ & 0.13 \\
\hline \multirow[t]{2}{*}{ Testosterone } & Exp & $1.32^{\mathrm{e}}$ & $3.30^{f}$ & $1.51^{\mathrm{e}}$ & $1.80^{\mathrm{e}}$ & $1.27^{\mathrm{e}}$ & $0.78^{\circ}$ & \\
\hline & Inexp & $0.91^{e}$ & $1.81^{e}$ & $0.88^{e}$ & $1.39^{e}$ & $0.77^{e}$ & $1.43^{e}$ & 0.34 \\
\hline
\end{tabular}

Different superscripts in the same row and in the same column for each hormone indicate statistically significant differences $(P<0.05)$. Per 1: pretreatment period; Per 2 : presence of stimulative ewes. 
Similarly, stimulation with non-receptive ewes led to a significant increase in $\mathrm{LH}$ peak frequency in both groups of rams. The degree of response was lower in experienced rams stimulated with nonreceptive compared to receptive ewes $(P<$ $0.05)$. This was not the case for inexperienced males, which showed an equivalent response regardless of the female's receptivity. The average testosterone level was significantly increased only in the group of experienced rams exposed to sexually receptive females (table I).

As expected, the non-receptive ewes were not mated and were mounted less frequently than the receptive animals. There were no statistically significant differences in the frequency of the other patterns of sexual behavior following exposure to receptive or non-receptive ewes (table II).

\section{DISCUSSION}

Our results show that the sexual experience of males affects their endocrine response to the presence of females: when stimulated by sexually receptive females, they show a higher increase in LH peak frequency and mean testosterone levels. Conversely, the sexual receptivity of the female does not influence the response in inexperienced rams. This fact is in agreement with some results obtained in rodents: sexually experienced male rats show higher LH and testosterone increases after sexual encounters with receptive females than inexperienced animals (Kamel et al, 1975). In addition, although inexperienced male mice present some increase in LH (Maruniak and Bronson, 1976), experienced males show a shorter latency period between stimulation and $\mathrm{LH}$ increase (Clancy et al, 1988).

Non-receptive ewes induce some degree of response both in experienced and inexperienced rams. This raises the question of the sexual specificity of the stimulation. In fact, it appears to depend on the sex of the animal introduced into the group of males. In an unpublished experiment, we have observed that introducing castrated males into a group of inexperienced rams did not elicit an endocrine response. The lower endocrine responses in sexually

Table II. Observations on behavior of sexually experienced (E) and inexperienced (I) rams (No/ram/ $4 \mathrm{~h})$.

\begin{tabular}{|c|c|c|c|c|c|}
\hline & \multicolumn{2}{|c|}{$\begin{array}{l}\text { Stimulated with } \\
\text { receptive ewes }\end{array}$} & \multicolumn{2}{|c|}{$\begin{array}{c}\text { Stimulated with } \\
\text { non-receptive * ewes }\end{array}$} & $\begin{array}{l}\text { Pooled } \\
\text { SD }\end{array}$ \\
\hline Sniffing & $17.1^{a}$ & $14.4^{a}$ & $23.2^{\mathrm{a}}$ & $23.4^{\mathrm{a}}$ & 14.0 \\
\hline Flehmen & $3.2^{\mathrm{a}}$ & $1.3^{a}$ & $4.0^{\mathrm{a}}$ & $1.6^{\mathrm{a}}$ & 1.4 \\
\hline Nudging & $16.1^{a}$ & $8.6^{a}$ & $25.0^{a}$ & $14.6^{a}$ & 12.0 \\
\hline Moulting & $14.1^{\mathrm{a}}$ & $6.8^{a}$ & $0.6^{b}$ & $1.6^{\mathrm{b}}$ & 0.9 \\
\hline Ejaculation & $1.41^{a}$ & $0.9^{a}$ & - & - & 0.8 \\
\hline
\end{tabular}

Oifferent superscripts in the same row denote statistically significant differences $(P<0.05)$. Ovariectomized nontreated ewes. 
inexperienced rams may be related to a difficulty in determining the physiological state of ewes.

The existence of some endocrine response observed in the absence of ejaculation in both groups stimulated with nonreceptive females supports our earlier results showing a lack of association between sexual activity and endocrine response (Gonzalez et al, 1988a, b).

The reason for the relatively high frequency of $\mathrm{LH}$ pulses in inexperienced unstimulated controls is not clear. The point can be raised as to whether the response of the stimulated groups of inexperienced males is due to some artifact which is independent of stimulation by females. However, it was only in the stimulated groups, and not in the control, that a significant increase was observed during the periods of stimulation. This confirms that stimulated males did in fact respond to the introduction of females.

\section{CONCLUSION}

In conclusion, rams appear to react to the presence of females by changes in their endocrine secretion irrespective of experience, physiological condition of the female, and sexual activity. Thus, despite a high variability in nudging, mounting and ejaculation in the groups of inexperienced males, or in experienced rams with nonreceptive ewes, a similar level of endocrine response is observed. On the other hand, experienced rams respond more strongly to receptive than to non-receptive females, or than inexperienced rams to sexually receptive ewes. This suggests: i), that males have learnt to determine the physiological and/or behavioral state of receptivity of the female; and ii), that this is capable of modifying the neuroendocrine control of gonadotropin secretion.

\section{ACKNOWLEDGMENTS}

We thank V Picketty, G Venier, E Archer and J Cohen-Tannoudji for valuable assistance. We also thank I Fontaine, C Kuntz and D André for technical assistance in RIA procedures, $Y$ Combarnous for providing the standard for $\mathrm{LH}$ assays, and $P$ Willshaw for help with the English. Roque Gonzalez was supported by a grant from the INTA Fellowship Program (Argentina).

\section{REFERENCES}

Clancy AN, Singer AG, Macrides $F$, Bronson FH, Agosta WC (1988) Experimental and endocrine dependence of gonadotropin responses in male mice to conspecific urine. Biol Reprod 38, 183-191

Coquelin A, Bronson FH (1980) Secretion of luteinizing hormone in male mice: factors that influence release during sexual encounters. Endocrinology 106, 1224-1229

Ellendorff $F$, Parvizi D, Pomerantz DK, Hartjen A, König A, Smidt D, Elsaesser F (1975) Plasma luteinizing hormone and testosterone in the adult male pig: 24-hour fluctuations and the effect of copulation. $J$ Endocrinol 67 , 403-410

Garnier DH, Cotta Y, Terqui M (1978) Androgen radio-immunoassay in the ram: results of direct plasma testosterone and dehydroepiandrosterone measurement and physiological evaluation. Ann Biol Anim Biochim Biophys 18, 265-281

Gonzalez R, Poindron P, Signoret JP (1988a) Temporal variation in $\mathrm{LH}$ and testosterone responses of rams after the introduction of oestrous females during the breeding season. J Reprod Fertil 83, 201-208

Gonzalez R, Orgeur P, Signoret JP (1988b) Luteinizing hormone, testosterone and cortisol responses in rams upon presentation of oestrous females in the nonbreeding season. Theriogenology $30,1075-1086$

Gonzalez R, Orgeur P, Poindron P, Signoret JP (1989) Seasonal variation in the LH and testosterone responses of rams following the introduction of oestrous ewes. Anim Reprod Sci $21,249-259$ 
Haltmeyer GC, Eik-Nes KB (1969) Plasma levels of testosterone in male rabbits following copulation. J Reprod Fertil 19, 273-277

Herndon JG, Perachio AA, Turner JJ, Collins DC (1981) Fluctuations in testosterone levels of male Rhesus monkeys during copulatory activity. Physiol Behav 26, 525-528

Kamel F, Mock EJ, Wright WW, Frankel Al (1975) Alterations in plasma concentrations of testosterone, $\mathrm{LH}$ and prolactin associated with mating in the male rat. Horm Behav 6 , 277-288

Katongole CB, Naftolin F, Short RV (1971) Relationship between blood levels of luteinizing hormone and testosterone in bulls and the effects of social stimulation. $J$ Endocrinol 50 , 457-466

Macrides F, Bartke A, Fernandez F, D'Angelo W (1974) Effect of exposure to vaginal odor and receptive females on plasma testosterone in the male hamster. Neuroendocrinology 15, 355-364

Macrides F, Bartke A, Dalterio S (1975) Strange females increase plasma testosterone levels in male mice. Science 189, 1104-1106

Maruniak JA, Bronson FH (1976) Gonadotropic responses of male mice to female urine. Endocrinology 99, 963-969

Merriam GR, Wachter KW (1982) Algorithms for the study of episodic hormone secretion. Am J Physiol 243, 310-318

Pelletier J, Garnier DH, De Reviers MM, Terqui M, Ortavant R (1982) Seasonal variation in $\mathrm{LH}$ and testosterone release in rams of two breeds. J Reprod Fertil 64, 341-346
Rich CE (1983) Repeated measures designs. In: Computer Packages and Research Design (Barcikowski RS, ed) Univ Press of America, Lanham, MD, vol 3, 567-613

Sanford LM, Palmer WM, Howland BE (1974) Influence of sexual activity on serum levels of $\mathrm{LH}$ and testosterone in the ram. Can J Anim Sci 54, 579-585

Schanbacher BD, Orgeur P, Pelletier J, Signoret JP (1987) Behavioural and hormonal responses of sexually experienced lle de France rams to estrus females. Anim Reprod Sci 14, 293-300

Siegel S (1956) Nonparametric Statistics for the Behavioral Sciences. McGraw-Hill Kogakusha, Tokyo

Sokal RR, Rohlf FJ (1981) Biometry. Freeman, San Francisco

Stevens J (1986) Applied Multivariate Statistics For the Social Sciences. L Erlbaum, New Jersey

SYSTAT (1985) Statistical Program: User's Guide. SYSTAT Inc, pp 416

Terqui M, Garnier DH, De Reviers MM, Huet S, Pelletier $J(1980)$ La structure chronologique du dialogue entre l'hypophyse et les gonades chez les mammifères domestiques. In: Rythmes et Reproduction (Ortavant R, Reinberg A, eds) Masson, Paris, 59-72

Yarney TA, Sanford LM (1983) The reproductive-endocrine response of adult rams to sexual encounters with estrual ewes is season dependent. Horm Behav 17, 169-182 